University of Nebraska - Lincoln

DigitalCommons@University of Nebraska - Lincoln

Biochemistry -- Faculty Publications

Biochemistry, Department of

2008

Development of SRAP, SRAP-RGA, RAPD, and SCAR markers linked with a Fusarium wilt resistance gene in eggplant

\author{
Nedim Mutlu \\ University of Nebraska - Lincoln, nmutlu2@unl.edu \\ Filiz Hatice Boyacı \\ Batı Akdeniz Agricultural Research Institute, Antalya, Turkey \\ Münevver Göçmen \\ Batı Akdeniz Agricultural Research Institute, Antalya, Turkey \\ Kazım Abak \\ University of Çukurova, Adana, Turkey
}

Follow this and additional works at: https://digitalcommons.unl.edu/biochemfacpub

Part of the Biochemistry, Biophysics, and Structural Biology Commons

Mutlu, Nedim; Boyacı, Filiz Hatice; Göçmen, Münevver; and Abak, Kazım, "Development of SRAP, SRAPRGA, RAPD, and SCAR markers linked with a Fusarium wilt resistance gene in eggplant" (2008). Biochemistry -- Faculty Publications. 91.

https://digitalcommons.unl.edu/biochemfacpub/91

This Article is brought to you for free and open access by the Biochemistry, Department of at DigitalCommons@University of Nebraska - Lincoln. It has been accepted for inclusion in Biochemistry -- Faculty Publications by an authorized administrator of DigitalCommons@University of Nebraska - Lincoln. 
Published in Theoretical and Applied Genetics: International Journal of Plant Breeding Research 117 (2008), pp. 1303-1312; doi: 10.1007/s00122-008-0864-6 Copyright @ 2008 Springer-Verlag. Used by permission.

Submitted June 12, 2008; accepted July 31, 2008; published online August 19, 2008.

\title{
Development of SRAP, SRAP-RGA, RAPD, and SCAR markers linked with a Fusarium wilt resistance gene in eggplant
}

\author{
Nedim Mutlu, ${ }^{1}$ Filiz Hatice Boyacı, ${ }^{2}$ Münevver Göçmen, ${ }^{2}$ and Kazım Abak ${ }^{3}$ \\ 1. Alata Horticultural Research Institute, Erdemli, Mersin, Turkey \\ 2. Batı Akdeniz Agricultural Research Institute, Antalya, Turkey \\ 3. Department of Horticulture, University of Çukurova, Adana, Turkey \\ Corresponding author - Nedim Mutlu, present address: Department of Biochemistry, University of Nebraska-Lincoln, \\ Lincoln, NE 68588, USA, email nmutlu2@unl.edu
}

\begin{abstract}
Fusarium wilt (Fusarium oxysporum Schlecht. f. sp. melongenae) is a vascular disease of eggplant (Solanum melongena L.). The objectives of this work were (1) to confirm the monogenic inheritance of fusarium wilt resistance in eggplant, (2) to identify molecular markers linked to this resistance, and (3) to develop SCAR markers from most informative markers. We report the tagging of the gene for resistance to fusarium wilt (FOM) in eggplant using SRAP, RGA, SRAP-RGA and RAPD markers. Analysis of segregation data confirmed the monogenic inheritance of resistance. DNA from $\mathrm{F}_{2}$ and $\mathrm{BC}_{1}$ populations of eggplant segregating for fusarium wilt resistance was screened with 2,316 primer combinations to detect polymorphism. Three markers were linked within $2.6 \mathrm{cM}$ of the gene. The codominant SRAP marker Me8/Em5 and dominant SRAP-RGA marker Em12/GLPL2 were tightly linked to each other and mapped $1.2 \mathrm{cM}$ from the resistance gene, whereas RAPD marker H12 mapped $2.6 \mathrm{cM}$ from the gene and on the same side as the other two markers. The SRAP marker was converted into two dominant SCAR markers that were confirmed to be linked to the resistance gene in the $\mathrm{F}_{2}, \mathrm{BC}_{1}$ and $\mathrm{F}_{2}$ of $\mathrm{BC}_{3}$ generations of the same cross. These markers provide a starting point for mapping the eggplant FOM resistance gene in eggplant and for exploring the synteny between solanaceous crops for fusarium wilt resistance genes. The SCAR markers will be useful for identifying fusarium wilt-resistant genotypes in marker-assisted selection breeding programs using segregating progenies of the resistant eggplant progenitor used in this study.
\end{abstract}

\section{Introduction}

Eggplant is widely grown in both open fields and greenhouses in Asia, Africa, and the subtropics, including the southern USA and the Mediterranean region. Eggplant is susceptible to numerous diseases particularly fusarium (Fusarium oxysporum Schlecht. f. sp. melongenae, FOM), verticillium (Verticillium dahliae) and bacterial (Ralstonia solanacearum) wilts (Kalloo and Berg 1993; Sihachakr et al. 1994). FOM is a major soil-borne pathogen and one of the causal agents of vascular wilt disease in eggplant. The fungus penetrates through the roots and proliferates in the vascular tissue. Wilting progresses from lower to upper leaves, followed by collapse of the plant. The pathogen has been identified in the open field as well as in greenhouse areas in several countries (Altinok 2005; Steekelenburg 1976; Stravato et al. 1993). Because fusarium fungi are widespread and persist for several years in the soil, a long crop rotation (4-6 years) with cereals and grasses, avoiding the use of any solanaceous crop, is necessary to reduce fungal populations (Mishra and Rath 1986). Strategies to control the dis- 
ease by soil fumigation are either costly or only applicable for greenhouse production (Gullino et al. 2002; Mandhare and Patil 1993). Host plant resistance is the best control method for environmental and financial reasons. Currently there are FOM resistant commercial eggplant rootstocks on which susceptible eggplant cultivars are grafted (Sato et al. 2004).

Resistance to FOM has been identified in S. melongena L. (Abdullaheva and Shifman 1988; Komochi et al. 1996; Mandhare and Patil 1993) and in related eggplant species Solanum indicum (imprecise name, possibly S. violaceum Ort.), S. aethiopicum L. Aculeatum Group (also found in literature as S. integrifolium Poir.), S. aethiopicum L. Gilo Group, S. torvum Sw., S. incanum L., S. violaceum Ort., and S. sisymbriifolium Lam. (Gousset et al. 2005; Rizza et al. 2002; Stravato et al. 1993; Yamakawa and Mochizuki 1979). Of the 60 accessions of eggplant collected in Malaysia, LS2436 and LS1934 were found to be resistant to FOM (Komochi et al. 1996; Monma et al. 1996). A single dominant gene was reported to confer resistance to FOM (Rotino et al. 2001; Yamakawa and Mochizuki 1979). The FOM resistance was also introgressed into S. melongena from different species including S. integrifolium (Okada et al. 2002; Rotino et al. 2001), S. aethiopicum L. Gilo Group (Rizza et al. 2002), and S. indicum (Rao and Kumar 1980). There has been no report in eggplant of the existence of FOM pathogen races or race specificity of resistance genes.

Two types of markers have become particularly useful to identify markers linked to disease resistance genes for resistance to plant pathogens. Sequence-related amplified polymorphism (SRAP) was first reported as a new and useful molecular marker system for tagging and mapping in Brassica oleracea L. because SRAP primers target coding sequences in the plant genome ( $\mathrm{Li}$ and Quiros 2001). Resistance gene analog (RGA) primers are also useful markers for tagging resistance genes and were designed from conserved motifs of the "Nucleotide Binding Site-Leucine Rich Repeat (NBS-LRR)" resistance gene family (Mutlu et al. 2006; Shen et al. 1998).

The identification of markers tightly linked to the locus that confers resistance to FOM allows the identification of individuals carrying the resistance gene and thus renders possible the use of marker-assisted selection
(MAS) for introgressing the gene of "LS2436" into other eggplant genotypes. The aims of this research were (1) to confirm the monogenic dominant control of fusarium wilt resistance in S. melongena, (2) to molecularly tag the gene for fusarium wilt resistance in eggplant using SRAP, RGA, SRAP-RGA, and RAPD markers, and (3) to develop SCAR markers from informative markers for use in MAS.

\section{Materials and methods}

\section{Plant materials}

The resistance source 'LS2436' is a S. melongena genotype from Malaysia. The susceptible source, 'NSFB99' is a cultivated eggplant line developed at Bati Akdeniz Agricultural Research Institute (BATEM) in Antalya, Turkey. Plant and fruit characteristics of both genotypes are as shown in Figure 1. 'LS2436' and 'NSFB99' (female parent) were crossed to generate $\mathrm{F} 1$ plants. The $\mathrm{F}_{1}$ plants were selfed and backcrossed to the susceptible parent to obtain segregating $\mathrm{F}_{2}$ and $\mathrm{BC}_{1}$ populations, respectively. Backcrossing continued for two more generations $\left(\mathrm{BC}_{3}\right)$ with phenotypic selection used to identify $B C$ plants resistant to FOM for use in subsequent cycles. The plants of the selfed generation of $\mathrm{BC} 3$ (generation noted $\mathrm{BC}_{3} \mathrm{~F}_{2}$ ) that were resistant to FOM were used for confirmation of linkage of the molecular markers. The DNA of 32 Solanum species related to eggplant (including wild forms of eggplant) was used to test the effectiveness of the SRAP and SCAR markers developed in this study. These accessions are conserved at Institut National de la Recherche Agronomique, Génétique et Amélioration des Fruits et Légumes, Montfavet, France (Table 1).

\section{Fusarium wilt phenotyping}

Phenotyping of the segregating populations for reaction to FOM was carried out in a climate-controlled greenhouse in BATEM, Antalya, Turkey. The seeds of the parents, $\mathrm{F}_{1}, \mathrm{~F}_{2}$ and $\mathrm{BC}_{1}$ populations were first sown in sterile planting medium where healthy seedlings were produced and maintained until inoculation. The exper-
Figure 1. Plant and fruit architectures of fusarium wilt susceptible 'NSFB99' (a) and resistant 'LS2436' (b) eggplant (Solanum melongena L.) genotypes
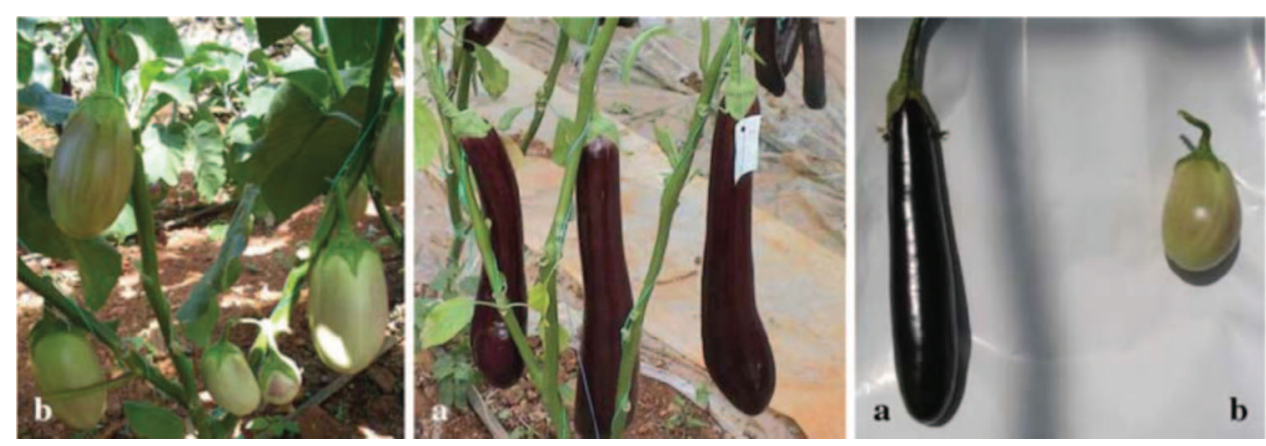
Table 1. Eggplant related species screened with the SRAP Me8/Em 5, SCAR426 and SCAR347 markers which are linked to S. melongena LS2436 gene conferring resistance against Fusarium oxysporum f. sp. melongenae (FOM)

\begin{tabular}{|c|c|c|c|}
\hline $\begin{array}{l}\text { INRA } \\
\text { accession no. }^{\text {a }} \\
\end{array}$ & Solanum species & $\begin{array}{l}\text { FOM } \\
\text { resistance }^{b}\end{array}$ & $\begin{array}{l}\text { SRAP Me8/Em 5, SCAR } \\
\text { and SCAR } \\
\text { S47 } \\
\text { markers }^{\mathrm{c}}\end{array}$ \\
\hline MM 0132 & Solanum macrocarpon L. & - & - \\
\hline MM 0150 & Solanum macrocarpon L. & $\mathrm{R}$ & - \\
\hline MM 0195 & Solanum linnaeanum Hepper \& Jaeger & - & - \\
\hline MM 0210 & Solanum campylacanthum Hochst. & - & - \\
\hline MM 0373 & Solanum scabrum Mill. & $\mathrm{R}$ & - \\
\hline MM 0374 & Solanum viarum Dun. & $\mathrm{R}$ & - \\
\hline MM 0376 & Solanum capsicoides All. & - & - \\
\hline MM 0497 & Solanum violaceum Ort. & $\mathrm{R}$ & - \\
\hline dMM 0498 & Solanum melongena L. group E & $\mathrm{R}$ & + \\
\hline MM 0574 & Solanum aethiopicum L. Kumba Group & $\mathrm{R}$ & - \\
\hline MM 0686 & Solanum melongena L. group F & - & - \\
\hline MM 0702 & Solanum incanum L. group A & - & - \\
\hline MM 0738 & Solanum melongena L. group $\mathrm{H}$ & - & - \\
\hline MM 0824 & Solanum marginatum L. fil. & - & - \\
\hline MM 0982 & Solanum anguivi Lam. & - & - \\
\hline MM 1005 & Solanum lidii Sunding & - & - \\
\hline MM 1010 & Solanum melongena L. group G & - & - \\
\hline MM 1137 & Solanum dasyphyllum Thonn. & - & - \\
\hline MM 1169 & Solanum aculeastrum Dunal. & - & - \\
\hline MM 1235 & Solanum burchellii Dunal & - & - \\
\hline MM 1248 & Solanum incanum L. group D & - & - \\
\hline
\end{tabular}

INRA accession numbers, as well as the information about the resistance to FOM of these accessions, when known, was provided by M. C. Daunay, INRA, UR 1052, F-84140 Montfavet

a. The accessions are conserved at INRA, UR 1052, F-84140 Montfavet

b. Eggplant genotypes that are resistant (R) against F. oxysporum f. sp. melongenae (personal communication: M. C. Daunay, INRA, UR 1052, F-84140 Montfavet)

c. Presence (+), or absence (-) of SRAPMe8/Em 5, SCAR426 and SCAR347 markers

$\mathrm{d}$. The eggplant accession that carries the SRAP and SCAR markers linked to the resistance gene against F. oxysporum f. sp. melongenae in eggplant

iment was conducted in a completely randomized design where $\mathrm{F}_{1}$ and parental plants were replicated three times with 15 plants in each replication. From the segregating populations, a total of $320 \mathrm{~F}_{2}$ and $400 \mathrm{BC}_{1}$ plants were tested for resistance against FOM. Similarly, advanced backcross generations $\left(\mathrm{BC}_{2} \mathrm{~F}_{1}, \mathrm{BC}_{3} \mathrm{~F}_{1}\right.$ and their selfed progenies, i.e., $\mathrm{BC}_{3} \mathrm{~F}_{2}$ ) were phenotyped by fusarium inoculation. A highly virulent Turkish FOM isolate that was identified in a previous study $(\mathrm{F} \cdot \mathrm{H}$. Boyacl, unpublished data) was used in a root-dip inoculation method modified from Pitrat et al. (1991). Four-weekold eggplant seedlings at the second true-leaf stage were used for inoculation. The roots of the seedlings were first washed with tap water and then wounded by trimming the tips. The roots were submerged for $5 \mathrm{~min}$ in a conidial suspension $\left(1 \times 10^{6}\right.$ conidia/mL) that was obtained from 7-day-old liquid culture as described by Pitrat et al. (1991), while control plants were immersed in sterile tap water. After inoculation, seedlings were transplanted into pots containing a mixture of sterile perlite and peat in the ratio of 1:1 $(\mathrm{v} / \mathrm{v})$, and maintained in a greenhouse at $20^{\circ} \mathrm{C}$ night and $27^{\circ} \mathrm{C}$ day. After 5 weeks, disease symptoms were evaluated according to Cappelli et al. (1995), where 1 = no disease symptoms; 2 = plants lacking one or two cotyledons; 3 = reduced growth of plants with yellowing of the leaves; $4=$ heavy stunting; 
$5=$ dead plants. Plants with ratings of 1 and 2 were considered resistant. For molecular tagging of the fusarium wilt resistance gene, $81 \mathrm{~F}_{2}$ (63 resistant and 18 susceptible) and $92 \mathrm{BC}_{1}$ (52 resistant and 40 susceptible) plants with disease symptoms recorded either as either 1 (resistant) or 5 (susceptible) were used.

\section{Molecular marker development}

\section{DNA extraction}

DNA of parents and segregating populations was extracted from young leaves using a modified CTAB extraction protocol (Doyle and Doyle 1990). For each sample, $0.2 \mathrm{~g}$ of fresh tissue was ground in $0.6 \mathrm{~mL}$ of extraction buffer [1.4 M of NaCl, $20 \mathrm{mM}$ of EDTA, $100 \mathrm{mM}$ of Tris-HCL ( $\mathrm{pH} 8), 2 \% \mathrm{CTAB}$, and $0.2 \%$ of beta-mercaptoethanol]. The suspension was mixed well, incubated at $60^{\circ} \mathrm{C}$ for $30 \mathrm{~min}$ followed by chloroform-isoamyl alcohol (24:1) extraction and precipitation with $2 / 3$ volume of isopropanol at $-20^{\circ} \mathrm{C}$ for $2 \mathrm{~h}$. The pellet formed after centrifugation at $13,100 \mathrm{~g}$ for $10 \mathrm{~min}$ was washed twice with $0.75 \mathrm{~mL}$ of $76 \%$ ethanol and $10 \mathrm{mM}$ of ammonium acetate, and then resuspended in sterile distilled water. A 1\% agarose-gel stained with ethidium bromide was used to measure concentration with a lambda DNA of known concentration. The DNA was stored at $-20^{\circ} \mathrm{C}$ until used.

\section{PCR amplification}

PCR reactions were performed in $15-\mu \mathrm{L}$ aliquots containing $1 \times$ buffer, $2 \mathrm{mM} \mathrm{MgCl}, 0.1 \mathrm{mM}$ dNTPs, $0.6 \mathrm{U}$ Taq polymerase (Biorun, Nantes, France), 3-10 $\mu \mathrm{M}$ primer and 10 ng DNA in a MJ research PTC-200 thermocycler (Bio-Rad, Hercules, CA). All PCR products were separated on a 1.5\% agarose gel (Sigma, St. Louis, MO), visualized with ethidium bromide staining under ultraviolet light, and photographed with a Kodak Gel Logic 200 system (Carestream Health, Rochester, NY).

SRAP analysis

The SRAP analysis was carried out using 29 primers including 13 forward (Me 1-13) and 16 reverse (Em 1-16) SRAP primers (Budak et al. 2004), for a total of 208 primer combinations. The PCR amplification conditions were as reported by Li and Quiros (2001).

\section{RGA analysis}

The RGA primers, previously reported by Mutlu et al. (2006), were designed from conserved regions of NBS-
LRR resistance genes of common bean (Phaseolus vulgaris L.). Twenty-eight RGA primers were used in 96 RGA primer combinations. The PCR amplification conditions were as reported by Mutlu et al. (2006).

SRAP-RGA analysis

For SRAP-RGA analysis, all 29 SRAP primers were used in combination with all 28 RGA primers, for a total of 812 primer combinations. Primer sequences of SRAP Em 12 and RGA GLPL2 are given in Table 2. Em 12 is one of the sixteen SRAP Em primers. GLPL2 is a degenerate primer that corresponds to one of the hydrophobic amino acid residues (amino acids GLPLAL) of the NBS-LRR type plant resistance gene family. PCR amplification conditions for SRAP-RGA were as follows; after an initial denaturing step at $94^{\circ} \mathrm{C}$ for $5 \mathrm{~min}$, products were amplified using 5 cycles of $94^{\circ} \mathrm{C}$ for $1 \mathrm{~min}, 38^{\circ} \mathrm{C}$ for $1 \mathrm{~min}, 72^{\circ} \mathrm{C}$ for $1 \mathrm{~min} 15 \mathrm{~s}$, and 35 cycles of $94^{\circ} \mathrm{C}$ for $45 \mathrm{~s}$, $55^{\circ} \mathrm{C}$ for $1 \mathrm{~min}, 72^{\circ} \mathrm{C}$ for $1 \mathrm{~min} 15$. Amplification concluded with a final elongation step at $72^{\circ} \mathrm{C}$ for $10 \mathrm{~min}$.

\section{RAPD analysis}

Twelve hundred 10-mer RAPD primers (Gene Link, NY) were used. PCR amplification involved an initial denaturing step at $94^{\circ} \mathrm{C}$ for $3 \mathrm{~min}$, followed by 35 cycles of $94^{\circ} \mathrm{C}$ for $1 \mathrm{~min}, 38^{\circ} \mathrm{C}$ for $45 \mathrm{~s}, 72^{\circ} \mathrm{C}$ for $2 \mathrm{~min}$. Amplification ended with a final elongation step at $72^{\circ} \mathrm{C}$ for $10 \mathrm{~min}$.

\section{SCAR design}

The 426-base pair (bp) amplified fragment of the codominant SRAP marker Me8/Em5 was excised from the agarose gel and purified with the OMEGA DNA purification system (Doraville, GA) according to manufacturer's instructions. The fragment was reamplified as described for SRAP protocol (Li and Quiros 2001). The PCR product was direct sequenced (Iontek Co., Istanbul, Turkey). Two specific oligonucleotides were then designed using the Vector NTI software (Invitrogen, Carlsbad, CA). The forward primer Me8SCAR2 contains the 17 bases of the SRAP primer Me8 plus the five adjacent bases (Table 2). The reverse primer Em5SCAR contains the $18 \mathrm{bp}$ of the original Em5 SRAP primer sequence plus the six adjacent bases (Table 2). The 20-bp-long Em5SCAR1 primer was designed about $80 \mathrm{bp}$ downstream of the Em5 priming site and does not share a common sequence with the Em5 SRAP primer. Amplification of genomic DNA with SCAR primers was carried out under the same conditions as the SRAP reaction described above, except that the extension time was reduced to $50 \mathrm{~s}$ and annealing temperature was raised to $57^{\circ} \mathrm{C}$ for Me8SCAR2/Em5SCAR, and $48^{\circ} \mathrm{C}$ for Me8SCAR2/Em5SCAR1. The $50 \mathrm{~s}$ 
Table 2. Sequence of oligonucleotide primers for SRAP, RAPD, RGA, and SCAR markers linked to a gene conferring resistance to Fusarium oxysporum Schlecht. f. sp. melongenae in eggplant (Solanum melongena)

\begin{tabular}{|c|c|c|c|}
\hline $\begin{array}{l}\text { Marker } \\
\text { type }\end{array}$ & $\begin{array}{l}\text { Primer } \\
\text { designation }\end{array}$ & $\begin{array}{l}\text { Primer } \\
\text { sequence }\left(5^{\prime}-3^{\prime}\right)\end{array}$ & $\begin{array}{l}\text { Size of the } \\
\text { marker (bp) }\end{array}$ \\
\hline SRAP & $\begin{array}{l}\text { Me } 8 \\
\text { Em } 5\end{array}$ & $\begin{array}{l}\text { TGA GTC CAA ACC GGA CT } \\
\text { GAC TGC GTA CGA ATT AAC }\end{array}$ & 426 \\
\hline SRAP & Em 12 & GAC TGC GTA CGA ATT CTC & 360 \\
\hline RGA & GLPL2 $^{a}$ & CA(AT)AG(AC)AA(AG)(AT)GG(AGC)A(AG)(AT)CC & \\
\hline RAPD & H12 & ACG CGC ATG T & 320 \\
\hline $\mathrm{SCAR}_{426}$ & $\begin{array}{l}\text { Me8SCAR2 } \\
\text { Em5SCAR }\end{array}$ & $\begin{array}{l}\text { TGA GTC CAA ACC GGA CTA CAA G } \\
\underline{\text { GAC TGC GTA CGA ATT AAC TCT ACG }}\end{array}$ & 426 \\
\hline $\mathrm{SCAR}_{347}$ & $\begin{array}{l}\text { Me8SCAR2 } \\
\text { Em5SCAR1 }\end{array}$ & $\frac{\text { TGA GTC CAA ACC GGA }}{\text { AGT TGA AAG GAA AGT AGG TG }}$ & 347 \\
\hline
\end{tabular}

Underlined region of SCAR primers represent the original sequences of SRAP primers. Sizes of the dominant markers that are linked to the resistance gene in coupling are given

a. Sequences in parenthesis indicate degeneracy at that point

extension time was optimal for both SCAR markers. The differences in G/C contents and lengths of Em5SCAR and Em5SCAR1 primers were the reason for the difference in annealing temperatures of SCARs. The SCAR primers designed were used to amplify DNA obtained from the 'LS2436' and 'NSFB99' parental lines, as well as the $\mathrm{BC}_{1}, \mathrm{~F}_{2}$, and $\mathrm{F}_{2}$ of $\mathrm{BC}_{3}$ and 32 related eggplant species (Table 1).

Bulked segregant analysis (BSA)

BSA was performed as reported previously (Michelmore et al. 1991). Bulked DNAs were prepared from equal volumes of standardized DNA of 10 resistant and 10 susceptible $\mathrm{F}_{2}$ plants. In addition to 208 SRAP, 96 RGA, and 812 SRAP-RGA primer combinations, 1,200 RAPD primers (Gene Link RAPD Decamer sets, NY) were used to screen resistant and susceptible bulks, for a total of 2,316 markers. A total of 16 primer combinations generated marker polymorphisms between resistant and susceptible bulks. Of the polymorphic markers, four were SRAPs, four were RGAs, six were SRAPRGAs, and two were RAPDs. These 16 markers were subsequently tested on the resistant and susceptible $\mathrm{F}_{2}$ individuals that made up the resistant and susceptible bulks.

Segregation and linkage analysis

Goodness-of-fit test $\left(\chi^{2}\right.$ analysis) was performed using Microsoft Excel spreadsheet software (Microsoft Corp., Redmond, WA) for the segregation ratios 3:1 (Resistant:Susceptible) for the $F_{2}$ and 1:1 (R:S) for the $\mathrm{BC}_{1}$. The linkage relationship of markers with the fusarium wilt resistance gene was estimated using Map- maker 3.0 software (Lincoln 1992), using a minimum LOD score of 5.0 and the Kosambi mapping function (Kosambi 1944).

\section{Results}

Genetics of fusarium wilt resistance in eggplant

Of the $320 \mathrm{~F}_{2}$ and $400 \mathrm{BC}_{1}$ plants phenotyped for reaction against FOM, 238 and 196 plants were resistant, and 82 and 204 plants were susceptible, respectively. It took 28 days for all plants of the susceptible parent (NSFB99) to wilt completely, whereas the resistant parent (LS2436) and $\mathrm{F}_{1}$ plants showed no symptoms 6 weeks post-inoculation. Chi-square analysis of disease reaction data indicated a good fit to the Resistant: Susceptible segregation ratios expected for a single dominant gene (Table 3): 3:1 $\left(\chi^{2}=0.067, P=0.80\right)$ for the $\mathrm{F}_{2}$ population and $1: 1$ $\left(\chi^{2}=0.16, P=0.69\right)$ for $\mathrm{BC}_{1}$ population.

Detection of markers linked to the fusarium wilt resistance gene

DNA bulks of both the resistant and susceptible $F_{2}$ plants were screened with a total of 2,316 primers and primer combinations. The 208 SRAP primer combinations yielded 598 bands, the 96 RGA primer combinations yielded 147 bands, and the 812 SRAP-RGA primer combinations yielded 983 bands. Of the 1,200 RAPD primers, 760 primers yielded a total of 2,476 scored bands. The average fragments generated per primer was 2.9 for SRAP, 1.5 for RGA, 1.2 for SRAP-RGA, and 3.3 for RAPD. Sixteen primers and primer combinations producing consistent and repeatable polymorphic bands 
Table 3. Reaction of $\mathrm{F}_{2}$ and $\mathrm{BC}_{1}$ plants from resistant 'LS2436' and susceptible 'NSFB99' eggplant (S.melongena) cross to Fusarium oxysporum Schlecht. f.sp. melongenae isolate

\begin{tabular}{llllll}
\hline Population & Resistant plants (no.) & Susceptible plants (no.) & Expected ratio & $\chi^{2}$ & Probability $(P)$ \\
\hline $\mathrm{F}_{2}$ & 238 & 82 & $3: 1$ & 0.067 & 0.80 \\
$\mathrm{BC}_{1}$ & 196 & 204 & $1: 1$ & 0.16 & 0.69 \\
\hline
\end{tabular}

between the resistant and susceptible parents were subsequently used for genotyping the individuals of the two bulks of $F_{2}$ plants ( 1 bulk of 10 resistant individuals, and 1 of 10 susceptible individuals). From these 16 markers, 3 detected clear-cut polymorphic bands, which were present in the resistant parent as well as in all individuals of the bulk "resistant," and were absent in the susceptible parent as well as in all individuals of the bulk "susceptible." The RGA markers that were polymorphic between resistant and susceptible bulks did not yield consistent polymorphisms when tested on individual plants of the bulks. One SRAP marker, one SRAPRGA marker, and one RAPD marker co-segregated with the resistance. SRAP primers Me8 and Em5 amplified a band of $426 \mathrm{bp}$, the combination of SRAP primer Em12 and RGA primer GLPL2 amplified a band of $360 \mathrm{bp}$, and RAPD primer H12 amplified a 320-bp band in resistant individuals. These three markers were selected for segregation analysis of the whole $\mathrm{F}_{2}$ (81 individuals) and $\mathrm{BC}_{1}$ (92 individuals) populations and amplification data revealed that all of them co-segregated with resistance: susceptibility in the ratio of 3:1 for $F_{2}$ and 1:1 for $\mathrm{BC}_{1}$ (Table 4). The recombination frequency observed in the $\mathrm{F}_{2}$ indicates that SRAP Me8/Em5 and SRAP-RGA Em12/GLPL2 markers are more tightly linked to fusarium wilt resistance gene (1 recombinant out of 81 plants observed, i.e., a distance of $1.2 \mathrm{cM}$ ) than RAPD H12 (2 recombinants out of 81 plants, i.e., $2.5 \mathrm{cM}$ ). Furthermore, the SRAP and SRAP-RGA markers co-segregated in both $\mathrm{F}_{2}$ and $\mathrm{BC}_{1}$ populations (Table 4 ).
The SRAP primer pair (Me8/Em5) actually generated a codominant marker and when the 350-bp fragment specific to the allele of susceptibility (amplified in the susceptible parent and individuals of the susceptible bulk) was sequenced, it showed extensive sequence identity to the 426-bp fragment in the resistant parent but also showed a 70-bp deletion. SRAP-RGA (Em12/GLPL2) as well as RAPD (H12) were dominant and linked in coupling phase. The linkage relationship of the markers with the resistance gene and each other showed that all three markers reside on one side of the resistance gene.

\section{Conversion of SRAP marker Me8/Em5 into SCAR markers}

The complete SRAP Me8/Em5 and SRAP-RGA Em12/ GLPL2 marker fragments were sequenced from both ends. The codominant SRAP marker Me8/Em5 located $1.2 \mathrm{cM}$ from the fusarium wilt resistance gene was converted into dominant SCAR markers as described elsewhere (Paran and Michelmore 1993). However, attempts to convert SRAP-RGA Em12/GLPL2 marker into CAPS (cleaved amplified polymorphic sequence) or SCAR failed. Extension of the forward and reverse primers caused loss of polymorphism, and restriction digests with different enzymes did not yield any polymorphism between resistant and susceptible parents. Only weak homologies were found between the sequenced marker fragments and known sequences in the database using

Table 4. Segregation of SRAP marker Me8/Em5, SRAP-RGA marker Em12/GLPL2, and RAPD marker H12 with resistance and susceptibility in segregating $\mathrm{F}_{2}$ and $\mathrm{BC}_{1}$ populations derived from a cross between Fusarium oxysporum Schlecht. f.sp. melongenae resistant 'LS2436' and susceptible 'NSFB99' eggplant (Solanum melongena) lines

\begin{tabular}{|c|c|c|c|c|c|c|}
\hline \multirow[t]{2}{*}{ Population } & \multirow[t]{2}{*}{ Marker type } & \multirow[t]{2}{*}{ Marker } & \multicolumn{2}{|c|}{ Absent (no.) } & \multicolumn{2}{|c|}{ Present (no.) } \\
\hline & & & Resistant & Susceptible & Resistant & Susceptible \\
\hline \multirow{3}{*}{$\mathrm{F}_{2}$} & SRAP & Me8/Em5 & 0 & 17 & 63 & 1 \\
\hline & SRAP- RGA & Em12/GLPL2 & 0 & 17 & 63 & 1 \\
\hline & RAPD & H12 & 0 & 16 & 63 & 2 \\
\hline \multirow[t]{3}{*}{$\mathrm{BC}_{1}$} & SRAP & Me8/Em5 & 1 & 39 & 51 & 1 \\
\hline & SRAP- RGA & Em12/GLPL2 & 1 & 39 & 51 & 1 \\
\hline & RAPD & H12 & 2 & 39 & 50 & 1 \\
\hline \multirow[t]{3}{*}{$\mathrm{F}_{2}$ of $\mathrm{BC}_{3}$} & SRAP & Me8/Em5 & 2 & - & 62 & - \\
\hline & SCAR & Me8SCAR2/Em5SCAR $\left(\mathrm{SCAR}_{426}\right)$ & 2 & - & 62 & - \\
\hline & SCAR & Me8SCAR2/Em5SCAR1 (SCAR $\left.{ }_{347}\right)$ & 2 & - & 62 & - \\
\hline
\end{tabular}

The SCAR markers were tested in resistant $\mathrm{F}_{2}$ of $\mathrm{BC}_{3}$ population of the same cross 
BLAST (Altschul et al. 1997), namely, between tomato (Solanum lycopersicum Mill.) genomic sequences, located on chromosome 8, AP009268.1 and SRAP Me8/Em5 marker fragment, and between AP009392.1 and SRAPRGA Em12/GLPL2 marker fragment.

From the complete sequence of SRAP Me8/Em5, three specific SCAR primers were designed containing between 40 and $50 \% \mathrm{G}+\mathrm{C}$. One forward primer was named Me8SCAR2 (5'-TGA GTC CAA ACC GGA CTA CAA G-3') and the two reverse primers were named Em5SCAR (5'-GAC TGC GTA CGA ATT AAC TCT ACG$\left.3^{\prime}\right)$ and Em5SCAR1 (5'-AGT TGA AAG GAA AGT AGG TG-3') (Table 2). The Me8SCAR2/Em5SCAR primers contained the original SRAP primer sequences of Me8 and Em5 at their 5' ends, respectively, and therefore the fragment produced after amplification with the SCAR primers was $426 \mathrm{bp}\left(\mathrm{SCAR}_{426}\right)$, the same length as the original SRAP marker. However, the Em5SCAR1 primer was designed about $80 \mathrm{bp}$ downstream of the Em5 SRAP primer binding site and the fragment produced for the resistance allele with Me8SCAR2/Em5SCAR1 SCAR primers $\left(\mathrm{SCAR}_{347}\right)$ is $347 \mathrm{bp}, 79 \mathrm{bp}$ shorter than the original SRAP fragment. SCAR ${ }_{426}$ amplified a single 426-bp band in the resistant $\mathrm{F}_{2}$ (Figure 2a) and $\mathrm{BC}_{1}$ (Figure $2 \mathrm{~b}$ ) plants, and $\mathrm{SCAR}_{347}$ produced two major bands, a 347-bp fragment for resistance allele and a 390-bp fragment in both resistant and susceptible genotypes of $\mathrm{F}_{2}$ (Figure 2c) and $\mathrm{BC}_{1}$ (Figure 2d). SCAR ${ }_{426}$ (Figure 2a, b) and $\mathrm{SCAR}_{347}$ (Figure 2c, d) markers yielded the same genotypic results (resistant: susceptible) on the parental lines, $\mathrm{F}_{2}$, and $\mathrm{BC}_{1}$ as those obtained recorded from $\mathrm{Me} 8$ / Em5 SRAP primers.

Out of 64 resistant plants of the $\mathrm{F}_{2}$ generation of $\mathrm{BC}_{3}$ that were selected after selection for resistance at each intermediate generation, two were recombinants for which the link between the two SCAR markers and fusarium wilt resistance gene was lost, and for those two plants the original SRAP Me8/Em5 marker was also missing (Table 4). From the formula (Allard 1999), $b=1-(1-c)^{n}$ where " $b$ " is the probability of breaking linkage between marker and the gene, $c$ is the recombination fraction $(1.2 \mathrm{cM})$, and $n$ is the number of backcrosses, $b$ would be expected to be $1-(1-0.012)^{3}=0.036(3.6 \%)$ in the $\mathrm{BC}_{3}$ generation. The probability of breaking linkage $(3.6 \%)$ in $\mathrm{BC}_{3}$ generation is thus close to the recombination rate we observed in $\mathrm{F}_{2}$ of $\mathrm{BC}_{3}$ (2 recombinants out of 64 plants, i.e., $3.1 \%)$.

Among 32 solanum accessions including a variety of wild and cultivated relatives as well as wild forms of eggplant, only one accession, S. melongena L. group E (MM0498) displayed the marker bands produced by both SCARs (Table 1). Interestingly, this accession is resistant (though partially) to fusarium wilt in France (M. C. Daunay, personal communication). Fusarium wilt resistant eggplant accessions include MM
284 S. sisymbriifolium Lam., MM 134 S. aethiopicum L. Aculeatum Group, MM 574 S. aethiopicum L. Kumba group, MM 232 bis S. aethiopicum L. Gilo Group, MM 373 S. scabrum Mill., MM 497 S. violaceum Ort., MM 374 S. viarum Dun., and MM 150 S. macrocarpon L. (Table 1) (M. C. Daunay, pers. commun.), however, none of these other accessions used displayed the marker bands (Table 1).

Although the SRAP Me8/Em5 marker was codominant, the SCAR markers derived from it showed dominant polymorphisms (associated with the dominant fusarium wilt resistant allele). Consequently, it was not possible to distinguish between the homozygote resistant and heterozygous resistant plants in $\mathrm{F}_{2}$ (Figure 2a, c) population.

\section{Discussion}

Results demonstrate monogenic dominant inheritance for the fusarium wilt resistance gene derived from eggplant line 'LS2436', thus confirming previous results (Rotino et al. 2001; Yamakawa and Mochizuki 1979), and that linkage between the resistance gene and several markers was established. The SRAP (Me8/Em5), the SRAP-RGA (Em12/GLPL2), and the RAPD (H12) markers were located at $1.2,1.2$, and $2.5 \mathrm{cM}$, respectively, from the resistance gene in the $\mathrm{F}_{2}$ population. In the $\mathrm{F}_{2}$ of $\mathrm{BC}_{3}$ population, the distance between the resistance gene and the SRAP (Me8/Em5) and its derived $\mathrm{SCAR}_{426}$ and $\mathrm{SCAR}_{347}$ was estimated as $3.1 \mathrm{cM}(2$ recombinant individuals out of 64). The SRAP (Me8/ Em5) marker locus was converted into SCAR markers $\left(\mathrm{SCAR}_{426}\right.$ and $\left.\mathrm{SCAR}_{347}\right)$ for the purpose of increasing the specificity of the reaction and of simplifying the use of markers linked to fusarium wilt resistance in eggplant breeding programs. To the best of our knowledge, this is the first report on the use of SRAP markers for tagging a simply inherited disease resistance trait in eggplant.

The novel approach in developing the SRAP Em12/ GLPL2 marker (where a SRAP primer was used in combination with an RGA primer to target the resistance genes) is adopted to map gene families. SRAP primers in combination with a gene-family specific primer with low degeneracy may enable detection of gene-family specific polymorphism. Indeed, we observed such polymorphisms with SRAP and RGA (designed from NBSLRR) primer combinations between our two parents, LS2436 and NSFB99 (data not shown). The position of the fusarium wilt resistance gene can be assigned to a particular region of the eggplant genome and to corresponding colinear genomic regions in other solanaceous crops using the sequences of the markers (Me8/Em5 and Em12/GLPL2) as probes. The I-2 gene confers resistance to FOL race 2 in tomato and belongs to the coiled 
Figure 2. Segregation of the dominant Sequence Characterized Amplified Region marker SCAR $_{426}$ (Figure $2 \mathrm{a}, \mathrm{b}$ ) and SCAR $_{347}$ (Figure 2c, d) linked to the locus for resistance to Fusarium oxysporum Schlecht. f.sp. melongenae in selected $\mathrm{F}_{2}$ (Figure $2 \mathrm{a}$, c) and $\mathrm{BC}_{1}$ individuals (Figure $2 \mathrm{~b}$, d) obtained from fusarium wilt resistant 'LS2436' and susceptible 'NSFB99' eggplant (Solanum melongenae L.) lines. The arrows indicate the polymorphic SCAR fragments linked to the resistance gene. $R P$ resistant parent, $S P$ susceptible parent, $R$ homozygote or heterozygote resistant individual, $S$ homozygote susceptible individual, $C$ control without template, $M$ size marker
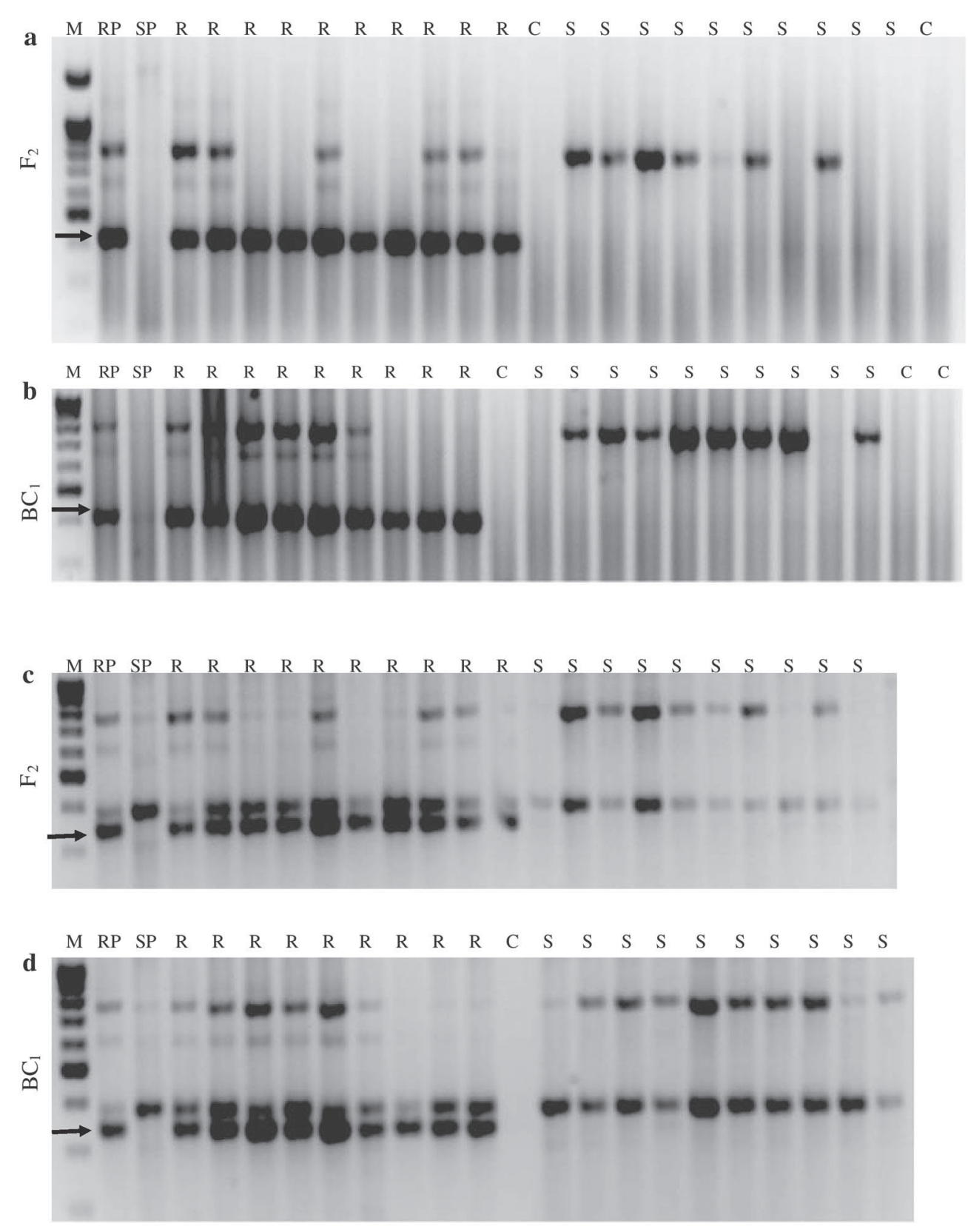

coil-nucleotide binding site-leucin rich repeat (CC-NBSLRR) class of plant resistance genes (Simons et al. 1998). Similarly, an RGA marker (RGA332), which was linked to the I-3 gene conferring resistance against race 3 of FOL, belonged to the Toll interleukin-1 (TIR)-NBS-LRR resistance gene class (Hemming et al. 2004). The SRAPRGA Em12/GLPL2 marker was expected to be part of an NBS-LRR gene because the GLPL2 primer was designed from the hydrophobic domain of the NBS-LRR gene family. However, sequence analysis of the marker fragment did not show similarity to sequences in the National Center for Biotechnology Information (NCBI) database.

The genetic relationship of the dominant resistance gene described here in eggplant with the resistance(s) which originate(s) from S. aethiopicum Gilo Group and wild eggplant species S. indicum, S. incanum, and S. integrifolium (Rotino et al. 2001; Yamakawa and Mochizuki 1979) is unknown. The monogenic dominant resistance to fusarium wilt derived from S. melongena confirms the previous inheritance results of the resistance obtained for S. integrifolium, i.e., S. aethiopicum Aculeatum Group (Rizza et al. 2002; Rotino et al. 2001) and S. aethiopicum Gilo Group (Rizza et al. 2002). Genetic stocks must be developed for all the fusarium wilt resistance genes originating from the different Solanum species, followed by allelism test amongst the resistance sources, as a basis for understanding the uniqueness and evolution of these resistance gene(s), and potential value for eggplant breeding. The resistance genes against FOM reported in eggplant and in its relatives may or may not be allelic depending on what point the resistance to fu- 
sarium wilt was acquired during the speciation of the genus Solanum. The SCAR markers linked with fusarium wilt resistance gene identified in 'LS2436', should be useful for MAS of this gene in diverse genetic backgrounds. Among 32 solanum accessions, including a variety of wild and cultivated eggplant relatives, the two SCARs amplified in only one accession, S. melongena group E-MM0498- (Table 1), a wild form of eggplant which is known to be partially resistant to fusarium wilt (Daunay, pers. commun.). The SCAR markers were not detected in any other Solanum accessions, including eight of them known to exhibit high levels of resistance (Table 4). This might indicate that either these accessions possess different resistance gene(s) than S. melongena L. (LS2436, MM0498), or that the linkage disequilibrium is lost between the marker locus and resistance gene(s) in these fusarium wilt resistant eggplantrelated species.

Another species of fusarium (F. oxysporum f. sp. lycopersici, FOL) causes vascular wilt in tomato and has three reported races (Alexander and Tucker 1945; Bohn and Tucker 1939; Grattidge and O'Brien 1982). Race specificity of fusarium resistance has apparently evolved after tomato speciation because resistance to the different races has been identified in two wild tomato species Solanum pimpinellifolium (resistance to race 1 and 2), and S. pennellii (resistance to race 3). However, physiological races of the wilt pathogen of eggplant have not been previously reported. The reason for this could be that the FOM pathogen has not experienced selection pressure from eggplant resistance gene(s) long enough or that this host-pathogen interaction has not been studied sufficiently.

Grube et al. (2000) compared RGA conservation across genera in the Solanaceae. Their study indicated that such genes map to syntenic positions in pepper (Capsicum annuum), potato (Solanum tuberosum) and tomato, but only in a few cases did the syntenic loci specify resistance to the same pathogen in the different genera. Sequence analysis of the SRAP Me8/Em5 and SRAP-RGA Em12/GLPL2 marker fragments showed weak homologies with tomato genomic sequences on chromosome 8, in the vicinity of RFLP marker T1581. This marker maps between RFLP markers CT148 and TG510 in eggplant (syntenic) chromosome 8 (Doganlar et al. 2002). There is no known fusarium resistance gene in tomato in this genomic region. An $R$ gene identified in the wild potato species Solanum bulbocastanum and conferring broad-spectrum resistance to Phytophthora infestans in cultivated potato and tomato (Vossen et al. 2003) was mapped close to this syntenic region of choromosome 8 region. Mapping of resistance genes has not been reported yet in eggplant, but RGA and SRAP markers are powerful tools that can render the identification and map localization of functional resistance genes much easier.
The SCAR markers $\left(\mathrm{SCAR}_{426}\right.$ and $\left.\mathrm{SCAR}_{347}\right)$ developed in this study should allow routine MAS for resistance against FOM from the resistance source 'LS2436' in eggplant breeding programs. This would permit an early selection of resistant genotypes without cumbersome steps of inoculation, waiting period and symptom detection. However, although these markers are close to the gene and the recombination rate is low, the presence, in the breeding material, of the resistance together with the marker bands needs to be ascertained via phenotyping tests regularly interspersed along the breeding steps. Molecular mapping and marker-assisted selection are innovative tools that have been used in research and breeding programs of many species to aid in the indirect selection and pyramiding of several resistance genes in a relatively shorter time period than classical breeding exclusively based on phenotyping. SCAR markers are more reproducible and easier to manipulate in MAS programs than other markers. Coupling-phase dominant markers linked to dominant resistance genes are equally effective as codominant markers in the successive backcrosses to breed an eggplant line carrying a resistance gene, since backcrosses produce only heterozygous genotypes. However, because of the dominant nature of the SCAR markers, both $\mathrm{F}_{2}$ and $\mathrm{F}_{3}$ selfing generations of final backcross populations need to be screened with the marker to identify non-segregating homozygote resistant lines. It would also be interesting to investigate whether the fusarium wilt resistance gene(s) identified and/or introgressed from related eggplant species are allelic to the eggplant gene reported in this study.

Acknowledgments - The financial support of The Scientific and Technological Research Council of Turkey (TUBITAK) (project no: 104 O 398) is gratefully acknowledged. Special thanks to M. C. Daunay, Anne Frary, and Sami Doganlar for providing DNA of eggplant-related species, and to Phillip Miklas, James Kelly, Stephen Baenziger, and Becky Higgins for critical review of the manuscript.

\section{References}

Abdullaheva K, Shifman IA (1988) Resistance of eggplant to fusarium wilt. Selektsiya i Semenovodstvo 1:29-31

Alexander LJ, Tucker CM (1945) Physiological specialization in the tomato wilt fungus Fusarium oxysporum f lycopersici. J Agric Res 70:303-313

Allard RW (1999) Principles of plant breeding, 2nd edn. Wiley, New York

Altinok HH (2005) First report of fusarium wilt of eggplant caused by Fusarium oxysporum f. sp melongenae in Turkey. Plant Pathol 54:577-579

Altschul SF, Madden TL, Schaffer AA, Zhang JH, Zhang Z, Miller W, Lipman DJ (1997) Gapped BLAST and PSI-BLAST: a new generation of protein database search programs. Nucl Acids Res 25:3389-3402 
Bohn GW, Tucker CM (1939) Immunity to fusarium wilt in the tomato. Science 89:603-604

Budak H, Shearman RC, Gaussoin RE, Dweikat I (2004) Application of sequence-related amplified polymorphism markers for characterization of turfgrass species. HortScience 39:955-958

Cappelli C, Stravato VM, Rotino GL, Bounaurio R (1995) Source of resistance among Solanum spp. to an Italian isolate of Fusarium oxysporum f. sp. melongenae. Eucarpia Meeting on genetics and breeding of Capsicum \& Eggplant. IX: 221-224

Doganlar S, Frary A, Daunay MC, Lester RN, Tanksley SD (2002) A comparative genetic linkage map of eggplant (Solanum melongena) and its implications for genome evolution in the Solanaceae. Genetics 161:1697-1711

Doyle JJ, Doyle JL (1990) Isolation of plant DNA from fresh tissue. Focus 12:13-15

Gousset C, Collonnier C, Mulya K, Mariska I, Rotino GL, Besse P, Servaes A, Sihachakr D (2005) Solanum torvum, as a useful source of resistance against bacterial and fungal diseases for improvement of eggplant (S. melongena L.). Plant Sci 168:319-327

Grattidge R, O'Brien RG (1982) Occurrence of a third race of fusarium wilt of tomato in Queensland. Plant Dis 66:165-166

Grube RC, Blauth JR, Arnedo MS, Caranta C, Jahn MK (2000) Identification and comparative mapping of a dominant potyvirus resistance gene cluster in Capsicum. Theor Appl Genet 101:852-859

Gullino ML, Minuto A, Garibaldi A (2002) Soil fumigation with chloropicrin in Italy: experimental results on melon, eggplant and tomato. Meded Rijksuniv Gent Fak Landbouwkd Toegep Biol Wet 67:171-180

Hemming MN, Basuki S, McGrath DJ, Carroll BJ, Jones DA (2004) Fine mapping of the tomato I-3 gene for fusarium wilt resistance and elimination of a co-segregating resistance gene analogue as a candidate for I-3. Theor Appl Genet 109:409-418

Kalloo G, Berg BO (1993) Genetic improvement of vegetable crops. Pergamon Press Ltd, Oxford, pp 587-604

Komochi S, Monma S, Narikawa T, Sakata Y (1996) Evaluation of resistance to bacterial wilt and verticillium wilt in eggplants (Solanum melongena L.) collected in Malaysia. J Jpn Soc Hortic Sci 65:81-88

Kosambi DD (1944) The estimation of map distances from recombination values. Ann Eugen 12:172-175

Li G, Quiros CF (2001) Sequence-related amplified polymorphism (SRAP), a new marker system based on a simple PCR reaction: its application to mapping and gene tagging in Brassica. Theor Appl Genet 103:455-461

Lincoln SE, Daly MJ, Lander ES (1992) Constructing genetic maps with MAPMAKER/Exp 3.0, 3rd ed. Whitehead Institute Technical Report, Whitehead Institute, Cambridge, MA

Mandhare VK, Patil PL (1993) Varietal screening and efficacy of fungicides against Fusarium wilt of brinjal. J Maharashtra Agric Univ 18:34-36

Michelmore RW, Paran I, Kesseli RV (1991) Identification of markers closely linked to disease-resistance genes by bulked segregant analysis: a rapid method to detect markers in specific genomic regions by using segregating populations. Proc Natl Acad Sci USA 88:9828-9832

Mishra D, Rath GC (1986) Control of Fusarium rot of eggplant. Indian J Agric Sci 56:612-616

Monma S, Sato T, Matsunaga H (1996) Evaluation of resistance to bacterial, Fusarium and Verticillium wilt in eggplant and eggplant-related species collected in Ghana. Capsicum Eggplant Nwsl 15:71-72
Mutlu N, Miklas PN, Coyne DP (2006) Resistance gene analog polymorphism (RGAP) markers co-localize with disease resistance genes and QTL in common bean. Mol Breed 17:127-135

Okada M, Yoshida T, Nitta M, Matsumoto M (2002) A new rootstock variety for eggplant. 'Daijirou' Bull Kochi Agric Res Ctr 11:53-61

Paran I, Michelmore RW (1993) Development of reliable PCRbased markers linked to downy mildew resistance genes in lettuce. Theor Appl Genet 85:985-993

Pitrat, M, Risser G, Epinat C, Ferrière C, Ricard M, Olivier C, Ruffinato A, Lecoq H, Blancard D, Bertrand F, Nicot A, Glandard A, Molot PM, Mas P (1991) Techniques d'inoculation artificielle du melon avec différents agents pathogènes pour la sélection de variétes résistantes. Informal technical Bulletin edited by INRA, Station d'Amélioration des Plantes maraîchères and Station de Pathologie végétale, Montfavet, France, p 8

Rao GR, Kumar A (1980) Some observations on interspecific hybrids of Solanum melongena L. Proc Indian Acad Sci Plant Science 89:117

Rizza F, Mennella G, Collonnier C, Shiachakr D, Kashyap V, Rajam MV, Prestera M, Rotino GL (2002) Androgenic dihaploids from somatic hybrids between Solanum melongena and S. aethiopicum group gilo as a source of resistance to Fusarium oxysporum f. sp melongenae. Plant Cell Rep 20:1022-1032

Rotino GL, Mennella G, Fusari F, Vitelli G, Tacconi MG, D'Alessandro A, Acciarri N (2001) Towards introgression of resistance to Fusarium oxysporum f. sp. melongenae from Solanum integrifolium into eggplant. Eucarpia Meeeting on Genetics and Breeding of Capsicum and Eggplant, Antalya, Turkey. XI: 303-307

Sato T, Yoshida T, Saito T, Sakata Y, Matsunaga H, Monma S (2004) Development of a new rootstock eggplant cultivar "Daizaburou" with high resistance to bacterial wilt and Fusarium wilt. Bull Natl Inst Veg Tea Sci 3:199-211

Shen KA, Meyers BC, Islam-Faridi MN, Chin DB, Stelly DM, Michelmore RW (1998) Resistance gene candidates identified by PCR with degenerate oligonucleotide primers map to clusters of resistance genes in lettuce. Mol Plant Microbe Interact 11:815-823

Sihachakr D, Daunay MC, Serraf I, Chaput MH, Mussio I, Haicour R, Rossignol L, Ducreux G (1994) Somatic hybridization of eggplant (Solanum melongena L.) with its close and wild relatives. In: Bajaj YPS (ed) Biotechnology in agriculture and forestry, somatic hybridization in crop improvement, vol I. Springer-Verlag, Berlin, pp 255-278

Simons G, Groenendijk J, Wijbrandi J, Reijans M, Groenen J, Diergaarde $\mathrm{P}$, Van der Lee T, Bleeker M, Onstenk J, de Both $\mathrm{M}$, Haring M, Mes J, Cornelissen B, Zabeau M, Vos P (1998) Dissection of the Fusarium I2 gene cluster in tomato reveals six homologs and one active gene copy. Plant Cell 10:1055-1068

Steekelenburg NV (1976) Fusarium wilt of eggplant in the Netherlands. Netherlands J Plant Pathol 82:191-192

Stravato VM, Cappelli C, Polverari A (1993) Fusarium oxysporum f. sp. melongenae agent of wilting of Aubergine. Inf Fitopatol 43:51-54

Vossen E, Sikkema A, Hekkert BL, Gros J, Stevens P, Muskens M, Wouters D, Pereira A, Stiekema W, Allefs S (2003) An ancient $R$ gene from the wild potato species Solanum bulbocastanum confers broad-spectrum resistance to Phytophthora infestans in cultivated potato and tomato. Plant J 36(6):867-882

Yamakawa K, Mochizuki H (1979) Nature and inheritance of Fusarium wilt resistance in eggplant cultivars and related wild Solanum species. Bull Veg Orn Crops Res Sta 6:19-27 